解 説

\title{
野生動物管理に関する法改正について
}

\author{
羽山伸一*
}

日本獣医生命科学大学獣医学部

\section{Law Amendment on Wildlife Management}

\author{
Shin-ichi HAYAMA*
}

School of Veterinary Medicine, Nippon Veterinary and Life Science University

\section{Summary}

In recent years, the wild animal issues became serious, and many related laws and regulations have been revised. In particular, as the number of deer and wild boars population increased, it became uncontrollable, so in 2014 the birds and animal protection law was revised and private enterprises and others were able to enter the capture project. However, it seems that these revisions will be effective for the time being.

野生動物問題の多様化かつ複雑化にともなって, ここ数 年で次々と関連する法制度が改正された。これらの改正の 眼目は, 従来の捕獲規制と許認可による行政システムから, 野生個体群と人間の関倸を順応的に調整するためのシステ ム（これを Wildlife management; 野生動物管理という）へ 転換することであった。ニホンザルの管理に関わる法改正 については, すでに羽山（2015）で報告している。本稿で は, これに加筆して大型野生動物の管理に関連する法制度 の内容と改正に伴う課題を概説する。

\section{2 年改正動物愛護管理法}

「動物の愛護及び管理に関する法律」は, 1973 年に議員 立法で制定された「動物の保護及び管理に関する法律」が 1999 年に大幅に改正されたものだ。当初, 本法は総理府の 所管だったが，2001 年の中央省庁再編に伴い，環境省に 移管され，自然環境局に設置された動物愛護管理室が所掌 している。この法律は, 野生鳥獣や外来生物の管理等の施 策と密接に関わるため, 環境省が所管するメリットは大き い一方で, 実際の現場の担当は主に保健衛生行政（保健所 等)であることから，その実効性を問題視する意見もある。

連絡先: 羽山伸一*

日本獣医生命科学大学獣医学部

干180-8602 東京都武蔵野市境南町 1-7-1

Tel : 0422-31-4151 ; Fax : 0422-34-6201

E-mail : hayama@nvlu.ac.jp
本法は，人と関わりのある動物（ただし野生状態の野生 動物は含まない）を対象として, 虐待の防止や適切な取り 扱い（愛護）と，人の身体・財産に対する危害や迷惑の防 止等（管理）について，社会的な棵組みを定めている。ま た，旧動物保護管理法と較べて，動物の飼い主など管理者 の責務が強化されたこと, 動物取扱業者に都道府県知事等 への登録（99 年改正当時は届出）が義務づけられたこと, 虐待や遺裹に対する罰則が強化されたことなどが特徵とい える。

その後, 2005 年の一部改正では, 国の基本指針の策定 および都道府県による動物愛護管理推進計画の策定が定め られ，動物取扱業の適正化（届出制から登録制の変更や， 動物取扱責任者設置の義務化など）などが定められた。し かし, 虐待の定義があいまいであるため, 現行犯以外での 取締りが難しいことや，殺処分する際の基準が定められな いなどの課題が残る。

一方で，飼い主責任を明確化するため，特定動物（旧法 の危険動物）への個体識別措置が義務化されたため, マイ クロチップの普及が期待されている。なお，外来生物法で 特定外来生物に指定された動物種は, 特定動物から除外さ れることになった。

2013 年 9 月に施行された 2012 年改正法では, 特定動物 を飼養保管する許可申請の事項に,「特定動物の飼養が困 難になった場合の対処方法」が加わり，むやみに飼育する 者に制限を課すことで遺棄を防止できる可能性が高まっ 
た。この規定は, 新たな外来動物問題を生み出さないため の発生源対策と評価される。

\section{3 年改正外来生物法}

「特定外来生物による生態系等に係る被害の防止に関す る法律」は, 2005 年から施行された。本法は, 特定外来 生物による生態系, 人の生命・身体, 農林水産業への被害 を防止し, 生物の多様性の確保, 人の生命・身体の保護, 農林水産業の健全な発展に寄与することを通じて, 国民生 活の安定向上に資することを目的としている。

このため, 外来生物すべてを規制するものではない。 2017 年 3 月現在, この特定外来生物に指定されている鳥 獣は 30 種（種群を含む）である。指定された特定外来生 物は, その飼養, 栽培, 保管, 運搬, 輸入等が規制され, また生態系からの排除（防除）を行なうことが可能となっ た。

特定外来生物に指定され, 生態系からの排除が必要と判 断された場合には, 国は, その対策（防除）手法を公示し, それに基づいた防除計画を策定して生態系からの排除をす すめることになる。対象が鳥獣の場合は, 防除計画を策定 した場合に限って, 鳥獣法に基づく捕獲許可が不要となる など，生態系からの排除を進めやすくなる仕組みだ。

この法律の特徵は, 特定外来生物を指定する際に科学者 が関与することと, 法定計画である防除計画を民間団体で も策定することができる点だ。いずれも，外来生物対策が 多様な主体の参画なしにすすめられないという前提にたっ ているためで, 従来の規制的手法にはない新たな制度設計 となっている。

2014 年 6 月に施行された 2013 年改正外来生物法では, 外来生物の定義を改正し, これまで法の対象となっていな かった外来生物が交雑することにより生じた生物を, 外来 生物に含めることとなった。この結果, 和歌山県や千葉県 で問題となっているニホンザルとの交雑個体は, 特定外来 生物として扱うことが可能となり, 新たな遺棄も防止でき ることとなった。一方で, 外見上識別が困難な交雑個体は 対象とならず，鳥獣法の捕獲許可なしには対処できず，放 置されることとなった。

\section{4 年環境省・農林水産省共同声明}

2013 年末, 本州以南に生息するシカの個体数が約 260 万頭と推定され，このままの状況では 2025 年までに 500 万頭を突破すると環境省が発表した。これに対応すべく, 農林水産省等と連携して, 10 年間でシカやイノシシを半 減させる目標を立て，対策に乗り出すこととなった。

これと連動するように, 2014 年 4 月には同じく連名で 「ニホンザル被害対策強化の考え方」および「カワウ被害
対策強化の考え方」を発表し，ニホンザル加害群およびカ ワウ加害個体の半減を目標とすることとなった。これらの 背景には, サルとカワウもシカやイノシシと同様の対策を という与党からの働きかけが大きかったと想像される。

こうした政治的動きを背景として, 次に紹介するように 鳥獣保護法を大幅に改正して, 捕獲を規制する「保護」か ら，個体数削減を基調とした「管理」に施策の軸足を移す こととなった。

\section{4 年改正鳥獣法}

明治期の開国に伴って, 銃の自由化に対応するため, 1873 年に制定された鳥獣捕獲規制法として制定された「鳥 獣猟規則」をルーツとして, 1895 年の狩猟法で原型が形 成された。その後も乱獲が続いたため, 1918 年には狩猟 法を全部改正し, 狩猟鳥獣を指定するとともに, それ以外 の鳥獣の捕獲を禁止する現行法の基盤が整備された。しか し, その後, 第二次世界大戦を経るまで大きな制度改革は なく, カモシカの密猟が横行するなどしたため, さらに捕 獲の規制を強める政策が検討された。

1963 年に, 狩猟法を鳥獣保護及狩猟二関スル法律に改 名し, 鳥獣保護事業計画制度を導入し, 都道府県を単位と した捕獲規制中心の法制度が出来上がっていった。しかし， 計画制度は導入されたとはいえ, すでにこの当時には欧米 諸国で始まっていた科学的なデー夕にもとづく管理 (Wildlife management) の思想や体制整備は 1999 年の法改 正まで見送られることなる。

1999 年に特定鳥獣保護管理計画制度が創設され，鳥獣 保護法に新たな歴史がはじまった。しかし，この計画制度 の進展は思わしくなく, さらに近年の狩猟者の減少とシカ やイノシシの急増を背景に, さらなる制度設計が求められ てきた。ようやく 2014 年 5 月, 鳥獣保護法の改正案が国 会で成立し,「鳥獣の保護及び管理並びに狩編の適正化に 関する法律」(略称：鳥獣法) となった。

これは, 捕獲規制が基調の旧法から, 野生動物管理法へ と転換させるものだ。改正法では, シカなどの集中的かつ 広域的に管理を図る必要がある野生動物を環境大臣が「指 定管理鳥獣」として定め, 国や都道府県が積極的に管理事 業を展開することが期待されている。また, 野生動物の管 理能力があると知事が認定した専門事業者（認定捕獲等事 業者）に捕獲等の事業委託をした場合，指定管理鳥獣が対 象の場合は夜間銃猟を規制緩和するなどの仕組みが盛り込 まれた。

この結果，従来から農林水産省の交付金制度としてある 鳥獣被害対策特措法関連予算に加え, 2015 年から環境省 の交付金措置がスタートした。この交付金は, 国や都道府 県が鳥獣保護管理法に基づいた指定管理鳥獣捕獲等事業を 
実施する場合，その事業費に対して支援されるもので，ま た事業の全部または一部を認定鳥獣捕獲等事業者に委託す ることができる。これは, いわば野生動物管理事業の「公 共事業化」とも言える制度であり, また野生動物管理の専 門技術者が社会認知された初めての制度でもある。

今のところ指定管理鳥獣としてシカとイノシシが指定さ れている。一方, 前述の共同声明にあるように, 二ホンザ ルやカワウを指定すべきという声は大きい。しかし，サル やカワウの個体群管理技術が標準化されていない現状か ら, むやみな捕獲が強化されることによって地域的な乱獲 や群れの分裂による被害拡大などが懸念されるため, しば らくは指定が見送られている。

\section{鳥獣法改正に関わる人材不足の課題}

こうして保護から管理へ転換を果たした鳥獣法である が, 法改正によって本来的に必要なのは行政の専門技術者 (マネージャー) であった。今回の法改正に先立って出さ れた中央環境審議会答申でも，管理法への転換とともに， 繰り返し専門技術者の必要性を述べている。また，これま でも鳥獣法の改正案が国会に上程されるたびに，このこと が付帯決議として示されながら, 今回の改正でも, その配 置を法制化できなかった。

2007 年に議員立法された鳥獣被害防止特措法では, 専 門技術者の育成を国や自治体に努力義務として課し, 市町 村には被害対策実施隊を配置するよう求めている。しかし, 実施隊は非常勤職と定められ，ここでいう専門技術者では なく, 現場の実行組織の位置づけである。いわば消防士が いないので，とりあえず消防団を設置したに等しい。そも そも, その主体と期待された狩猟者も高齢化が深刻で, 捕 獲目標を達成できない地域が広がっている。

もっとも, 民が先行して国の形を変えてきた歴史は分野 を越えていくつもある。自治体や大学等の教育機関は改正 法に対応できる人材育成を進めなければならない。今回の 改正によって, 野生動物管理の専門技術者が社会に位置づ けられ, 有為な若者が職業として目指すようになることが 期待される。この法改正にあたって, 科学的・計画的な管 理を効果的に推進するため, 野生動物管理に関する専門的 な知見を有する職員が都道府県に配置されることが重要で あるという観点から, 国会の附帯決議で, その配置状況に ついて国が把握し, 毎年公表することが求められた。これ は, 都道府県が認定した認定鳥獣捕獲等事業者を指揮監督 する責任が都道府県担当職員にあるというだけではなく， 公的資金で実施される指定管理鳥獣捕獲等事業の成果を挙 げるためには高度な専門的知識や経験が必要であるから だ。

2016 年 4 月現在の都道府県における専門的職員の配置
状況が環境省から公表されたが, 全都道府県で鳥獣行政 （農林部局を含む）を担当している職員 4278 名の内, 専門 的職員 141 名が 37 都道府県に配置されていることが明ら かとなった。すなわち, 専門的職員の割合は $3.3 \%$ で, 常勤・ 非常勤職員別の割合は, 常勤職員 $7.7 \%$, 非常勤職員 $1.3 \%$ となっていた。9 道県では専門的職員を 5 名以上配置して いる一方で, 10 県では 1 名の配置もなく, 前述の課題が 裏付けられる結果となった。国情が異なるので比較にはな らないが, 例えば行政機関に 1 万名以上の野生動物専門技 術者が雇用されている米国などと日本では, 野生動物管理 体制の状況がかけ離れている。

これまで，こうした専門的職員を育成または確保する制 度は国, 自治体を問わず，ほとんど存在しなかった。そこ で, 農林水産省では2006 年から, イノシシ・シカ・サル 等野生鳥獣による農作物被害防止対策を効果的に実施する ため, 野生鳥獣の生態・行動や農作物被害防止対策に関す る専門的な知識や経験を有する者をアドバイザーとして登 録し, 地域の要請に応じて紹介する取組みを開始した。 2016 年現在で 197 名が登録されているが, 登録にあたっ ての客観的基準が無いなどの課題がある。また, 環境省も 専門技術者の登録制度を 2008 年から開始し, 2016 年現在 で 109 名が登録されている。こちらの登録には, 通算 5 年 以上の実務経験が応募要件となり, さらに第三者による審 査があるが, 明確な専門的知識や技術の達成基準が求めら れているわけではない。

いずれにしても，わが国で求められる野生動物管理専門 技術者の基準作りが求められており, その水準に達した専 門的職員が行政職員として配置されなければ，各地域にお ける対策の効果を担保できないと考えられる。2009年か ら宇都宮大学では鳥獣管理士育成プログラムがスタート し, この資格取得者が中心となって一般社団法人・鳥獣管 理技術協会が設立された。この協会では, 2015 年から CPD 制度（継続的専門能力開発システム）を利用した鳥 獣管理士認定制度を創設し, 明確な基準を設定した人材育 成と資格認定を行っている。

前述の認定捕獲等事業者のスキルアップや, 行政におけ る専門的職員の配置を進めるためには, こうした民間資格 を活用することが効果的であると考えられる。一方で，す でに50をこえる大学で野生動物管理にかかわる講義や実 習などが行われているという。また，国や自治体等でさま ざまな研修も実施され，これらのカリキュラムにおけるシ ラバスを統一化することが今後必要になるだろう。

そのためには，早急に各地域や実施主体における野生動 物専門技術者の育成目標像の構築と, 必要とされるスキル や知識を身につけるための最低限のコア・カリキュラム策 定に国の支援が期待される。 


\section{参考文献}

羽山伸一, 坂元雅行 : 鳥獣保護法改正の経緯と評価. 環境 と公害，29，33-39， 2000.

羽山伸一：野生動物に関連する法制度と政策. 313-330, 文永堂出版, 東京, 2013.

羽山伸一：野生動物管理の時代. 環境と公害, 43，1，2014. 羽山伸一 : ニホンザルの管理に関する法律の改正と今後の

課題. 霊長類研究, 31，61-62， 2015.
環境省：動物の愛護及び管理に関する法律. 環境省, 東京. Available at : http://www.env.go.jp/nature/dobutsu/aigo/1_law/ 環境省 : 特定外来生物による生態系等に係る被害の防止に 関する法律．環境省，東京．Available at：http://www.env.go. $\mathrm{jp} /$ nature/intro/2law/index.html

環境省：鳥獣の保護及び管理並びに狩猟の適正化に関する 法律. 環境省, 東京. Available at : http://www.env.go.jp/press/ press.php?serial $=17875$ 